\title{
The hydrochemistry of high-elevation lakes in the Georgia Basin, British Columbia
}

\author{
Donna STRANG*, Julian AHERNE and D. Patrick SHAW ${ }^{1)}$ \\ Environmental and Life Sciences, Trent University, 1600 West Bank Drive, Peterborough, ON K9J 7B8, Canada \\ ${ }^{1)}$ Environment Canada, 201-401 Burrard Street, Vancouver, BC V6C 3S5, Canada \\ *e-mail corresponding author: donnastrang@trentu.ca
}

ABSTRACT

High-elevation lakes are sensitive to acidification from atmospheric deposition owing to their generally small catchment areas, thin soils and low bedrock weathering rates. The Georgia Basin, southwest British Columbia, Canada, receives atmospheric inputs from emissions originating in Vancouver, Victoria, and from marine traffic in the Strait of Georgia. There is growing concern on the influence of this air pollution on high-elevation systems in the region. Water chemistry and catchment characteristics were used to assess the sensitivity of 72 lakes in the Georgia Basin to acidic deposition. Twenty percent of the study lakes had pH levels less than 6, and acid neutralising capacity (ANC) concentrations below $20 \mu \mathrm{eq} \mathrm{L}^{-1}$, which are key thresholds for biological sustainability. Base cation and trace metal concentrations were low, typical of the dilute nature of high-elevation lakes (median conductivity $=7.0$ $\mu \mathrm{S} \mathrm{cm}^{-1}$ ). Nonetheless, concentrations of trace metals (such as lead) decreased with distance from major cities. The primary factors influencing the $\mathrm{pH}$ and $A N C$ of surface waters were investigated using multiple linear regression; both ANC and $\mathrm{pH}$ were related to longitude and the proportion of the catchment dominated by ice and glaciers. Increasing sulphur deposition resulted in decreasing $\mathrm{pH}$. The median critical load of acidity (sulphur) for the study lakes was approximately $70 \mathrm{meq} \mathrm{m}^{-2} y^{-1} ; 18 \%$ of the lakes received sulphur deposition (range: 6-81 meq $\mathrm{m}^{-2} \mathrm{y}^{-1}$ for the period 2005-2006) in excess of their critical load.

Key words: acidification, sulphur and nitrogen deposition, long-range transboundary air pollution, acid neutralising capacity, critical loads, Canada

\section{INTRODUCTION}

High-elevation catchments are characterized by dilute surface waters, small terrestrial areas, limited vegetative cover, thin soils and low bedrock weathering rates (Psenner 1989; Drever \& Zobrist 1992). As such, they are sensitive to surface water acidification and eutrophication owing to atmospheric acid (Psenner 1989; Mosello et al. 1995) and nitrogen (N) deposition respectively (Williams et al. 1996a; Campbell et al. 2000). Accordingly, high-elevation lakes are considered early warning systems to the impacts of long-range air pollution. Synoptic water chemistry surveys have played an integral role in identifying the major factors influencing surface water chemistry and in assessing lake sensitivity (Baron 1992; Marchetto et al. 1994; Jeffries et al. 2010, this issue; Scott et al. 2010, this issue). Acid neutralising capacity (ANC) and its relation to catchment characteristics have been commonly used to assess sensitivity to acidic atmospheric deposition (Sullivan et al. 2007; Nanus et al. 2009).

The Georgia Basin, located in the southwest corner in British Columbia (BC), Canada, encompasses the major cities of Vancouver and Victoria (Fig. 1). There is growing concern on the influence of atmospheric deposition (specifically sulphur (S) and N) on the high-elevation catchments that dominate this mountainous region. Continental-scale model simulations indicate that the Georgia Basin receives high levels of S and $\mathrm{N}$ deposition (Moran et al. 2008). The response of high-elevation systems to these pollutants has been studied in many regions in the world. Lake surveys in the Italian Alps found that the major acidifying agents were $\mathrm{S}$ and $\mathrm{N}$ deposited from the atmosphere (Mosello et al. 1990; Marchetto et al. 1995). Similarly, lake surveys in the Tatra Mountains, Slovakia, indicated that during peak acid deposition, the $\mathrm{pH}$ of high-elevation lakes decreased substantially to a median $\mathrm{pH}$ of 5.3 (Stuchlik et al. 2006). High surface water nitrate $\left(\mathrm{NO}_{3}{ }^{-}\right)$concentrations were related to atmospheric $\mathrm{N}$ deposition (Stuchlik et al. 2006), a trend also observed in lakes in the Rocky Mountains of Colorado (Williams et al. 1996a; Clow et al. 2002).

The sensitivity of surface waters to acid deposition has been widely assessed using the effects-based critical load approach, defined as "a quantitative estimate of an exposure to one or more pollutants below which significant harmful effects on specified sensitive elements of the environment do not occur according to present knowledge" (Nilsson \& Grennfelt 1988). Lakes in the Georgia Basin have long been suspected as highly sensitive to acid deposition because the region is dominated by acidic rocks with poor weathering capacity (Weins 1987). Few studies have assessed the sensitivity of lakes in the Georgia Basin to long-range air pollution (Sullivan \& Samis 1988; Swain et al. 1985). Moreover, lake 


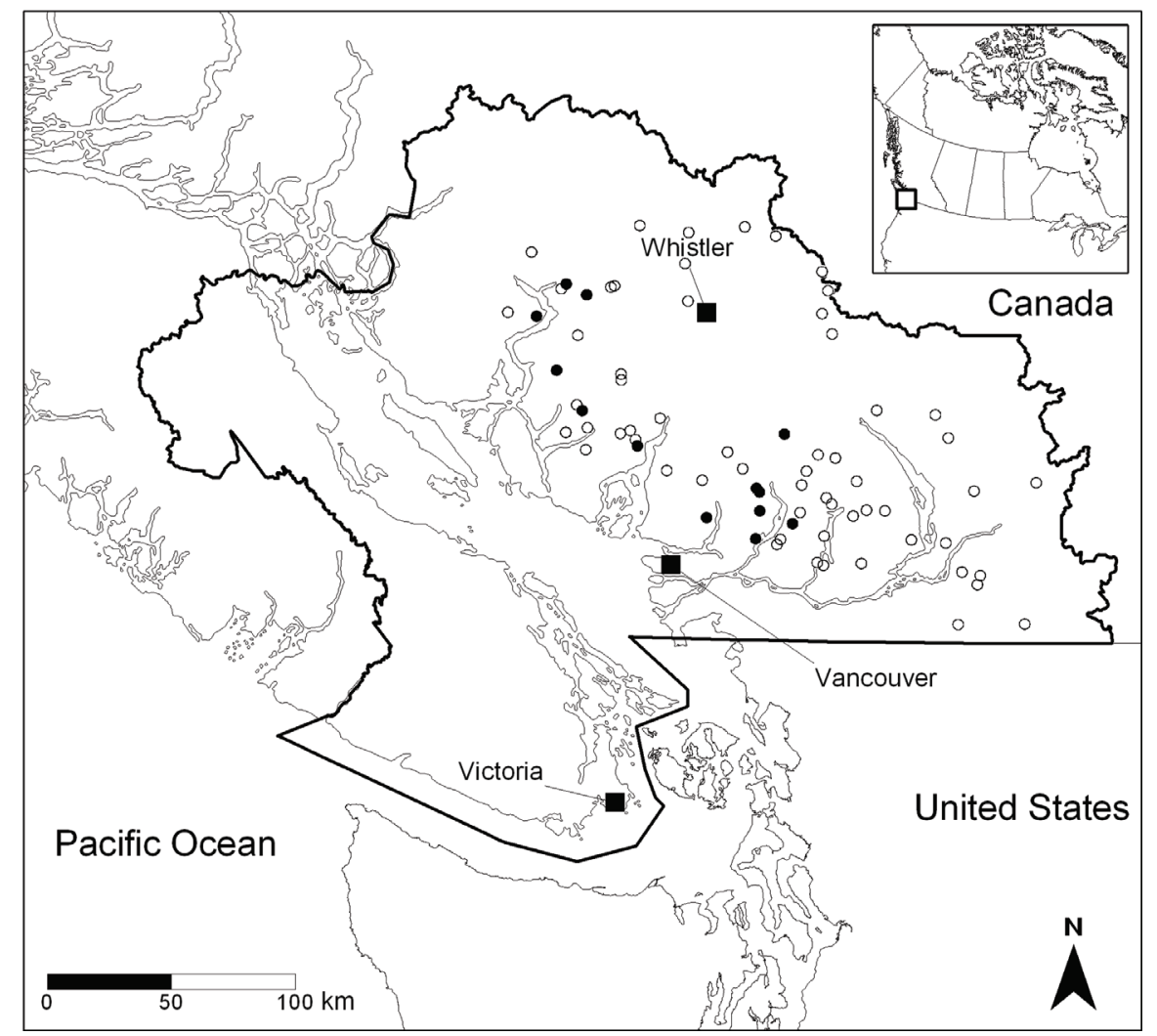

Fig. 1. Location of the Georgia Basin, British Columbia, Canada (delineated by bold black line). The study lakes are denoted by circles (filled circles indicate lakes that receive sulphur deposition in excess of their critical load) while major cities are denoted by filled squares.

surveys conducted in the mid-1980s focussed on readily accessible or large (insensitive) water bodies.

During October 2008, a survey of high-elevation lakes $(\mathrm{n}=72)$ was carried out within the Georgia Basin. The objectives of this study were to: (a) describe the hydrochemistry of high-elevation lakes, (b) assess their acid sensitivity by investigating the primary factors influencing chemical composition, and (c) determine the critical load and exceedance of acidity (S) for the study lakes.

\section{METHODS}

\subsection{Study area}

The Georgia Basin encompasses $48,000 \mathrm{~km}^{2}$ and is surrounded by four mountain ranges; the Olympic Mountains, Vancouver Island Ranges, the Coast Ranges and the Cascades. The area receives high levels of precipitation especially along the coastal regions as a result of orographic precipitation. Moreover, due to the variable topography, air masses and their associated pollutants can be trapped leading to potentially high atmospheric deposition. The major emitters of $\mathrm{S}$ and $\mathrm{N}$ within the basin include the marine, transportation and industrial sectors (Environment Canada 2004). The basin encompasses seven biogeoclimatic zones (regions characterized as having specific climates, soils and vegetation communities): coastal Douglas fir (CDF), coastal west- ern hemlock, mountain hemlock, interior Douglas fir, montane spruce, Engelmann spruce-subalpine fir and the alpine tundra (AT) zones (Meidinger \& Pojar 1991). Temperatures within these zones vary greatly, with mean annual temperatures ranging from $10.5^{\circ} \mathrm{C}$ in the low elevation $\mathrm{CDF}$ zone to $-4.0^{\circ} \mathrm{C}$ in the high altitude AT zone (Meidinger \& Pojar 1991).

\subsection{Field sampling and laboratory analysis}

In October 2008, 72 high-elevation lakes were sampled within the Georgia Basin (Fig. 1). The lakes were chosen based on lithology; the majority of the lake catchments being dominated by the rock types of granodiorite and quartz diorite, both characterized by low buffering capacity and low weathering rates. The elevation of the study lakes ranged between 90 and $2005 \mathrm{~m}$ a.s.l. with $65 \%$ of lakes $\geq 1000 \mathrm{~m}$ a.s.l. (Tab. 1).

Water collections were made centre-lake from a float-equipped Bell 206 helicopter. Water depths were measured using an Eagle Cuda168 ${ }^{\mathrm{TM}}$ depth sounder with a float-mounted transducer and the position was logged using a Garmin $76 \mathrm{~S}^{\mathrm{TM}}$ global positioning unit. Surface water conductivity, $\mathrm{pH}$ and temperature were measured in situ using a Yellow Springs Instrument Model 6600 sonde. Near-surface water samples were collected using pre-cleaned plastic bottles. Samples were dispensed into individual analytical bottles and 
Tab. 1. Summary statistics for the study lakes $(n=72)$ including both chemical and morphological characteristics (P25 refers to the $25^{\text {th }}$ percentile while P75 refers to the $75^{\text {th }}$ percentile). ${ }^{\S}:$ DOC $=$ dissolved organic carbon.

\begin{tabular}{|c|c|c|c|c|c|c|}
\hline Variable & Mean & Min & $\mathrm{P} 25$ & Median & P75 & Max \\
\hline Elevation (m) & 1145 & 90 & 880 & 1174 & 1442 & 2005 \\
\hline Lake area (ha) & 43 & 4 & 8 & 16 & 41 & 629 \\
\hline Watershed area (ha) & 731 & 26 & 135 & 261 & 390 & 16892 \\
\hline Alpine/Barren (\%) & 50.7 & 0.0 & 21.1 & 56.1 & 78.3 & 100.0 \\
\hline Forested (\%) & 33.4 & 0.0 & 0.7 & 29.1 & 61.0 & 100.0 \\
\hline Ice and glacier (\%) & 3.7 & 0.0 & 0.0 & 0.0 & 0.3 & 62.4 \\
\hline Precipitation $\left(\mathrm{mm} \mathrm{y}^{-1}\right)$ & 3218 & 1627 & 2488 & 3184 & 3829 & 4974 \\
\hline $\mathrm{S}$ deposition $\left(\mathrm{kg} \mathrm{ha}^{-1} \mathrm{y}^{-1}\right)$ & 3.75 & 1.01 & 2.13 & 3.55 & 4.38 & 11.71 \\
\hline $\mathrm{N}$ deposition $\left(\mathrm{kg} \mathrm{ha}^{-1} \mathrm{y}^{-1}\right)$ & 8.65 & 2.07 & 4.56 & 6.98 & 10.60 & 37.23 \\
\hline Conductivity $\left(\mu \mathrm{S} \mathrm{cm}^{-1}\right)$ & 9.43 & 2.00 & 4.00 & 7.00 & 10.50 & 43.00 \\
\hline Alkalinity $\left(\mu \mathrm{eq} \mathrm{L}^{-1}\right)$ & 78.2 & 19.0 & 38.3 & 61.3 & 101 & 287 \\
\hline $\mathrm{pH}$ & 6.44 & 5.44 & 6.13 & 6.42 & 6.85 & 7.32 \\
\hline $\mathrm{Ca}^{2+}\left(\mu \mathrm{eq} \mathrm{L}{ }^{-1}\right)$ & 57.9 & 3.19 & 20.0 & 43.8 & 63.40 & 346.82 \\
\hline $\mathrm{Mg}^{2+}\left(\mu \mathrm{eq} \mathrm{L}{ }^{-1}\right)$ & 9.21 & 1.23 & 3.50 & 5.68 & 10.9 & 49.9 \\
\hline $\mathrm{K}^{+}\left(\mu \mathrm{eq} \mathrm{L} \mathrm{L}^{-1}\right)$ & 3.87 & 0.69 & 1.66 & 2.66 & 3.87 & 20.1 \\
\hline $\mathrm{Na}^{+}\left(\mu \mathrm{eq} \mathrm{L}{ }^{-1}\right)$ & 16.8 & 4.18 & 11.1 & 13.9 & 19.8 & 53.9 \\
\hline $\mathrm{Cl}^{-}\left(\mu \mathrm{eq} \mathrm{L} \mathrm{L}^{-1}\right)$ & 5.46 & 1.41 & 1.41 & 4.23 & 6.53 & 36.20 \\
\hline $\mathrm{SO}_{4}{ }^{2-}\left(\mu \mathrm{eq} \mathrm{L} \mathrm{L}^{-1}\right)$ & 17.5 & 2.08 & 5.52 & 8.54 & 15.3 & 169 \\
\hline $\mathrm{NO}_{3}^{-}\left(\mu \mathrm{eq} \mathrm{L}{ }^{-1}\right)$ & 1.73 & 0.18 & 0.18 & 0.78 & 2.35 & 9.71 \\
\hline $\mathrm{NH}_{4}^{+}\left(\mu \mathrm{eq} \mathrm{L} \mathrm{L}^{-1}\right)$ & 0.24 & 0.18 & 0.18 & 0.18 & 0.18 & 1.10 \\
\hline $\mathrm{ANC}\left(\mu \mathrm{eq} \mathrm{L} \mathrm{L}^{-1}\right)$ & 63.0 & 5.95 & 21.8 & 60.7 & 78.8 & 246 \\
\hline $\mathrm{DOC}\left(\mathrm{mg} \mathrm{L}^{-1}\right)^{\S}$ & 1.12 & 0.15 & 0.42 & 0.74 & 1.60 & 7.22 \\
\hline Organic anion $\left(\mu \mathrm{eq} \mathrm{L}^{-1}\right)$ & 7.80 & 1.01 & 2.93 & 5.29 & 11.4 & 45.8 \\
\hline
\end{tabular}

kept cool for shipment to laboratories (within approximately 24 hours).

Water samples were analyzed for $\mathrm{pH}$, total alkalinity by titration, major anions by ion chromatography, ammonium and total phosphate by colourimetry, and dissolved organic carbon (DOC) by combustion following $0.45 \mu \mathrm{m}$ membrane filtration and metals by ICP and ICP-MS. External quality assurance involved blind submission of blanks and sample duplicates. Further, the quality of the analytical data was checked by ion balance. Organic anion concentrations were calculated from DOC and $\mathrm{pH}$ following Oliver et al. (1983); ANC was estimated as the difference between the sum of base cations and sum of acid anions in $\mu$ eq $\mathrm{L}^{-1}$.

\subsection{Catchment data}

Catchment boundaries for the study lakes were delineated from a digital elevation model (DEM: 1:20,000 BC Ministry of Environment) using a geographic information system (GIS). Lake areas were obtained from the BC National Topographic Series $(1: 50,000)$ maps. Land-use data for each catchment were delineated from the 1:250,000 Baseline Thematic Mapping (version 2 BC Ministry of Environment), which was compiled from Landsat 7 imagery from 1999 onwards. Catchment lithology was delineated from the digital geology map of BC (1:250,000 BC Ministry of Energy, Mines and Petroleum Resources). Rock types were grouped into four buffering or weathering categories from Nanus et al. (2009) and the weathering sequence developed by Goldich (1938): (a) low buffering (e.g., gneiss, granite, diorite), (b) medium buffering (e.g., basalt, amphibolite), (c) high buffering (e.g., horneblende, olivine), and (d) unknown buffering (e.g., some sedimentary rocks). Precipitation data was extracted from the Parameter Elevation Regressions on Independent Slopes (PRISM: Daly et al. 1994) model, at a $4 \mathrm{~km}$ by $4 \mathrm{~km}$ grid resolution. Annual average total (wet and dry) S and $\mathrm{N}$ deposition for the period 2005-2006 was obtained from the Community Multiscale Air Quality (CMAQ: Di Cenzo \& Lepage 2003) model at a $4 \mathrm{~km}$ by $4 \mathrm{~km}$ grid resolution. Evaluations of the CMAQ model by Eder and $\mathrm{Yu}$ (2006) indicated good agreement between measured and modelled sulphate $\left(\mathrm{SO}_{4}{ }^{2-}\right)$ and ammonium $\left(\mathrm{NH}_{4}{ }^{+}\right)$deposition levels and markedly improved $\mathrm{NO}_{3}{ }^{-}$prediction compared to earlier CMAQ versions.

\subsection{Statistical analysis}

All statistical analyses were conducted using STATISTICA 7.0 and Kyplot 2.0; alpha values were set at 0.05 . The non-parametric Spearman rank-order correlation was conducted on all chemical and catchment characteristics as the majority of the data were not normally distributed (Kolmogorov-Smirnov, $p<0.05$ ). Only correlation results that were significant and pertinent to the objectives of the study are reported in detail. Explanatory models were developed using stepwise forward regression. The number of model variables was based on both model parsimony (minimizing explanatory variables) and model performance (ability to predict $\mathrm{ANC}$ and $\mathrm{pH}$ ). Models were limited to a maximum of four explanatory variables. All data were $\log _{10}$ transformed in the analysis of $\mathrm{pH}$, whereas only those that were not normally distributed were transformed for analysis of ANC determinants. 

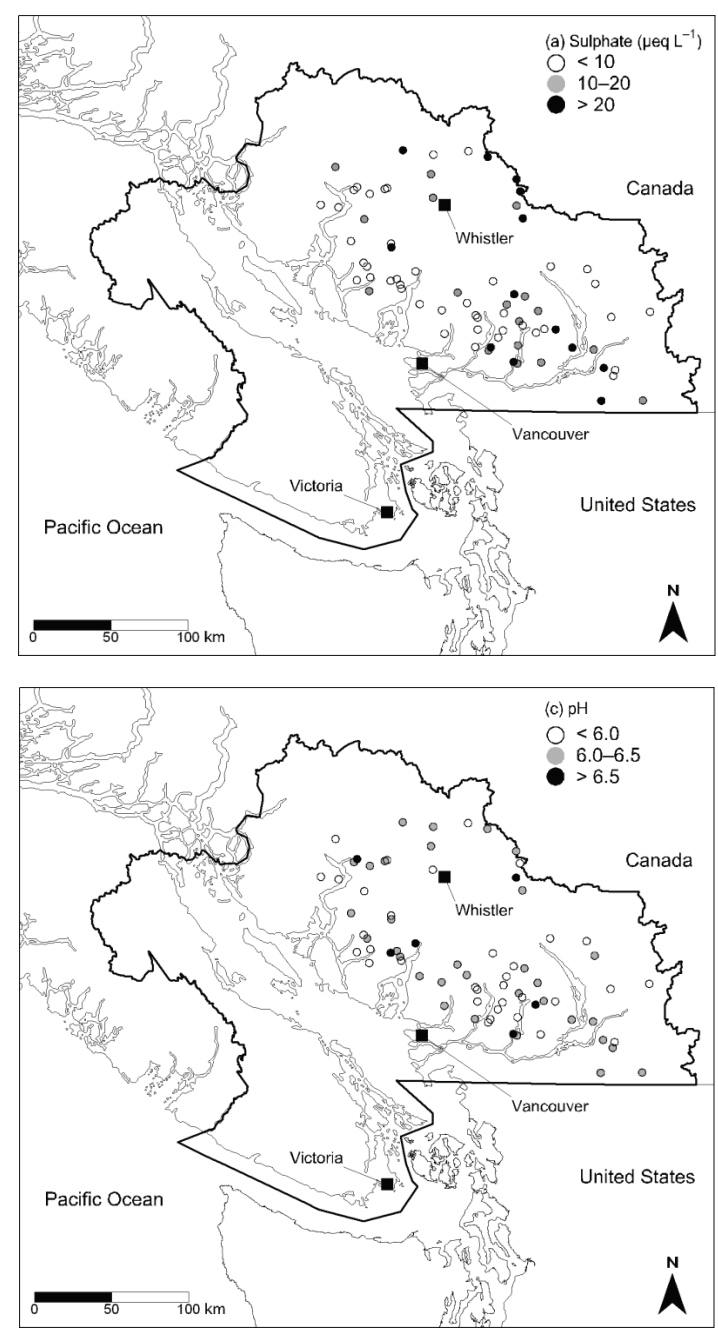
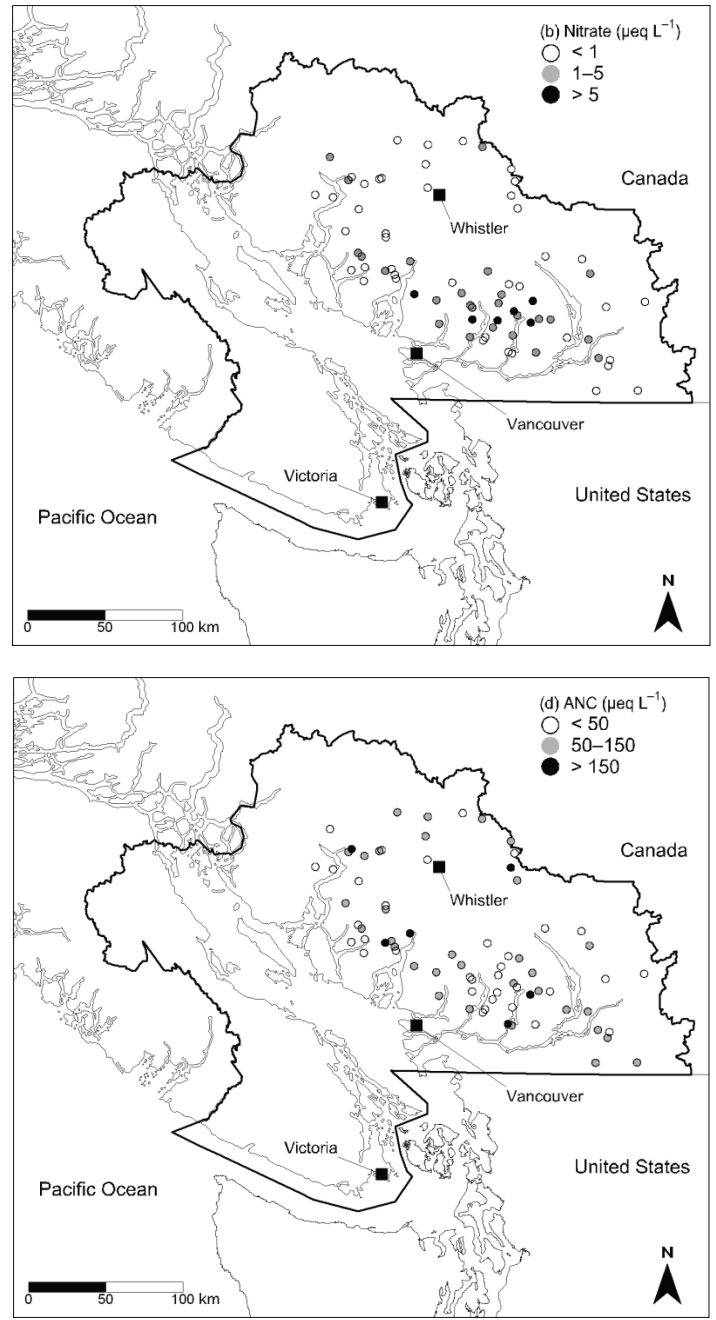

Fig. 2. Distribution of (a) sulphate, (b) nitrate, (c) $\mathrm{pH}$ and (d) ANC concentrations in the Georgia Basin.

\subsection{Critical loads}

The steady-state water chemistry (SSWC) model (Aherne et al. 2002; UBA 2004) was used to estimate the critical load of acidity $[\operatorname{CL}(A)]$ for the study lakes. The model incorporates a critical chemical limit $\left(\mathrm{ANC}_{\text {limit }}\right)$ to protect a selected biological indicator from significant harmful effects. A value of $20 \mu \mathrm{eq} \mathrm{L}^{-1}$ is commonly used to protect fish species (Lien et al. 1996); however, ANC is highly influenced by natural organic acids. The current study incorporated a lakespecific $\mathrm{ANC}_{\text {limit }}$ based on $\mathrm{DOC}\left(\mathrm{mg} \mathrm{L}^{-1}\right)$ following Lydersen et al. (2004):

$$
\mathrm{ANC}_{\text {limit }}=10+(10.2 / 3) \times \mathrm{DOC}
$$

The present exceedance of critical load $[\operatorname{Ex}(\mathrm{A})]$ was calculated as anthropogenic sulphate deposition (Sdep) plus present $\mathrm{N}$ leaching flux $\left(\mathrm{N}_{\text {leach }}\right)$ minus $\mathrm{CL}(A)$. Nitrogen is largely retained in terrestrial catchments, as such $\mathrm{N}$ deposition cannot be used directly to estimate exceedance. The current study included the acidifying impact of $\mathrm{N}$ deposition at present rates of $\mathrm{N}$ retention in the catchment (i.e., at present $\mathrm{N}$ leaching).
In addition to surface water acidification, $\mathrm{N}$ deposition can potentially cause terrestrial and aquatic eutrophication. Most plants are adapted to nutrient-poor conditions, and can only survive or compete successfully under low $\mathrm{N}$ availability. The nutrient impact of $\mathrm{N}$ deposition was evaluated using empirical critical loads (derived from field studies and experiments). Empirical critical loads in the range of $5-15 \mathrm{~kg} \mathrm{~N} \mathrm{ha}^{-1} \mathrm{y}^{-1}$ have been recommended for alpine terrestrial ecosystems (Achermann \& Bobbink 2003; UBA 2004). Furthermore, critical loads derived from changes in diatom assemblages in lakes in the Loch Vale catchment in Rocky Mountain National Park, Colorado have been proposed at $1.5 \mathrm{~kg} \mathrm{~N} \mathrm{ha}^{-1} \mathrm{y}^{-1}$ (Baron 2006).

\section{RESULTS AND DISCUSSION}

\subsection{Acidity, acid neutralising capacity and alkalinity}

The $\mathrm{pH}$ values for the 72 study lakes ranged from 5.44 to 7.32 (Tab. 1). Almost $20 \%$ of the lakes had pH values less than 6.0 (Fig. 2c), the level at which biological impacts are expected to occur (Jeffries 1997). There were no lakes, however, experiencing severe 

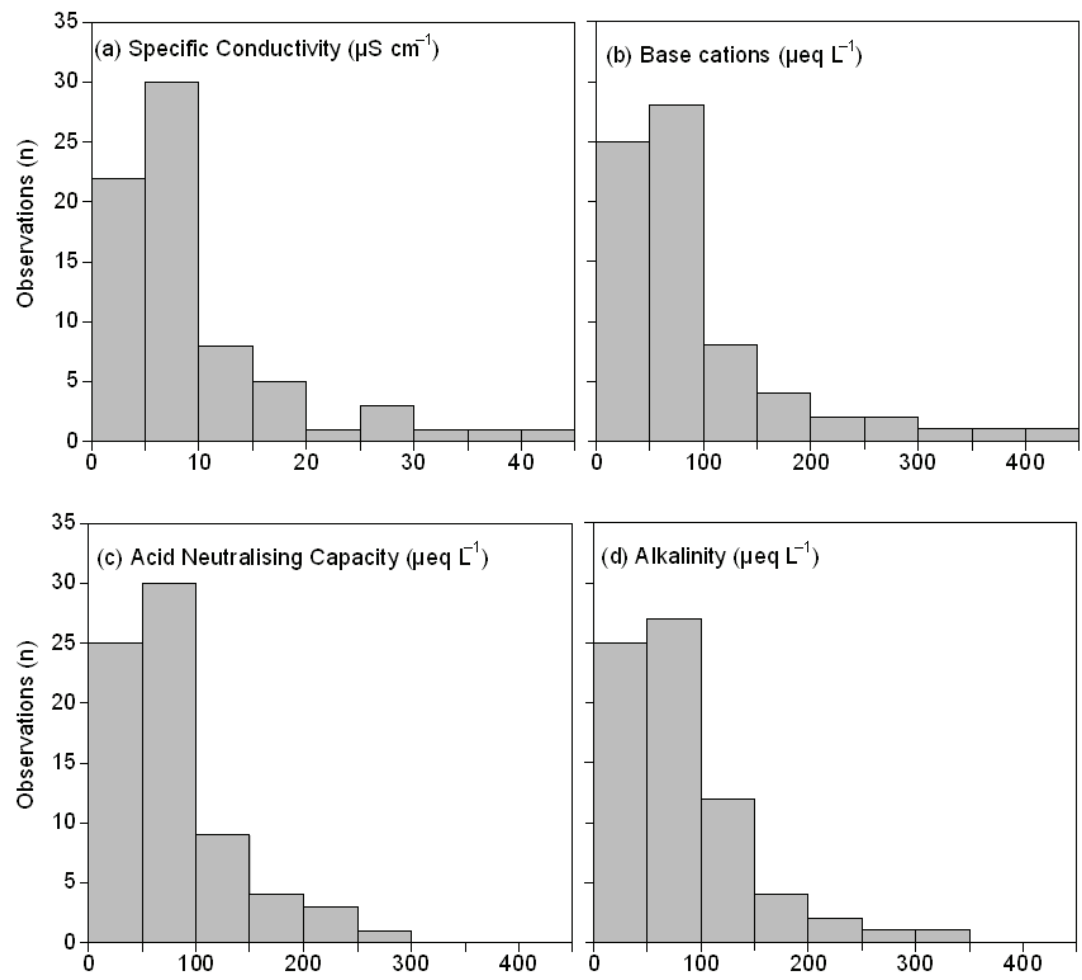

Fig. 3. Frequency distributions of (a) specific conductivity, (b) sum of base cations $\left(\mathrm{Ca}^{2+}, \mathrm{Mg}^{2+}, \mathrm{K}^{+}, \mathrm{Na}^{+}\right)$, (c) acid neutralising capacity $(\mathrm{ANC})$ and $(\mathbf{d})$ alkalinity for the study lakes $(\mathrm{n}=72)$.

acidification ( $\mathrm{pH} \leq 5.0)$ causing the mobilization of toxic forms of aluminium (Baker \& Schofield 1982). The $\mathrm{pH}$ values reported for the Georgia Basin, are comparable to those reported from mountainous regions of Europe, including the central and eastern Alps (Marchetto et al. 1995; Psenner 1989) and the Swiss Alps (Drever \& Zobrist 1992).

Most study lakes had low conductivities (Fig. 3a) and low alkalinity (Fig. 3d). Fifty-two (70\%) of the 72 lakes had specific conductivities less than $10 \mu \mathrm{S} \mathrm{cm}^{-1}$. The mean conductivity $\left(\approx 10.0 \mu \mathrm{S} \mathrm{cm} \mathrm{cm}^{-1}\right)$ is noticeably lower than remote lakes in many parts of the world (see Rogora et al. 2008). Alkalinity was also low, with the majority (74\%) of lakes having concentrations less than $100 \mu \mathrm{eq} \mathrm{L}{ }^{-1}$ (Fig. 3d). Acid neutralising capacity levels varied greatly between the lakes (between 5.95 and 246

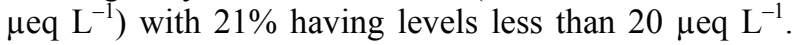
Acid neutralizing capacity thresholds are commonly used to evaluate the acid sensitivity of lakes. Using ANC thresholds suggested by Herlihy et al. (1993) and Sullivan et al. (2004), 34 of the study lakes within the Georgia Basin were sensitive to atmospheric deposition $\left(\mathrm{ANC} \leq 50 \mu \mathrm{eq} \mathrm{L}^{-1}\right.$ ), 6 lakes were insensitive (ANC $\geq 150 \mu \mathrm{eq} \mathrm{L}{ }^{-1}$ ) and 32 lakes were moderately sensitive (Figs $2 \mathrm{~d}$ and $3 \mathrm{c}$ ).

Significant negative correlations were observed between $\mathrm{pH}$ and both $\mathrm{S}$ deposition $\left(r_{\mathrm{s}}=-0.351, p=0.03\right)$ and precipitation $\left(r_{\mathrm{s}}=-0.572, p<0.001\right)$, indicating that increases in either is reflected by decreased $\mathrm{pH}$ levels in surface waters. Decreases in $\mathrm{pH}$ as a result of the at- mospheric deposition of S containing compounds has been documented in many aquatic systems worldwide and has been identified as a principal driver of acidification in freshwater systems (Schindler 1988; Aherne et al. 2002). Within the Georgia Basin, estimated S deposition ranged between approximately 1 and $12 \mathrm{~kg} \mathrm{ha}^{-1}$ $\mathrm{y}^{-1}$ (Tab. 1). Those lakes receiving the greatest $\mathrm{S}$ deposition also had the lowest $\mathrm{pH}$ values.

Increased precipitation in mountainous regions typically results in greater deposition loads of atmospheric pollutants compared with the surrounding low lying areas (Williams \& Tonnessen 2000). In the current study, lakes receiving precipitation amounts between 3500 and $5000 \mathrm{~mm} \mathrm{y}^{-1}$ had S deposition rates as high as $11 \mathrm{~kg} \mathrm{ha}^{-1} \mathrm{y}^{-1}$. Furthermore, 9 of the 14 lakes with $\mathrm{pH}$ $<6.0$ were observed within this precipitation range. As expected, in concert with $\mathrm{pH}$, ANC and alkalinity were found to decrease significantly with increasing precipitation amounts $\left(r_{\mathrm{s}}=-0.558, p<0.001\right.$ and $r_{\mathrm{s}}=$ $-0.603, p<0.001$, respectively).

In the majority of mountainous regions studied, $\mathrm{pH}$ decreases with increasing elevation, a feature attributed to the lower bedrock weathering rates at higher elevations (Drever \& Zobrist 1992). In the Georgia Basin, the opposite trend was true and $\mathrm{pH}$ increased with elevation $\left(r_{\mathrm{s}}=0.252, p=0.03\right)$. Lake catchments between 1000 and $1500 \mathrm{~m}$ a.s.l. received an average of $3510 \mathrm{~mm} \mathrm{y}^{-1}$, while those above $1500 \mathrm{~m}$ a.s.l. received an average of $2577 \mathrm{~mm} \mathrm{y}^{-1}$. These higher elevation lakes therefore have $\mathrm{pH}$ levels that are not as influenced by atmospheric 
inputs compared to lakes at lower elevations. In addition, organic anions have been shown to contribute to the acidification of freshwaters (Oliver et al. 1983; Kahl et al. 1989), especially in dilute lakes where small amounts of organic anions can result in substantial $\mathrm{pH}$ depression (Kahl et al. 1989). Organic anion concentrations in our study lakes ranged from 1.01 to $45.8 \mu \mathrm{eq} \mathrm{L}^{-1}$ (Tab. 1); and decreased significantly with increased elevation $\left(r_{\mathrm{s}}=-0.643, p<0.001\right)$, owing to decreased vegetative land cover and increased barren lands at high altitudes.

\subsection{Base cations, sulphate and nitrate}

Surface water base cations originate from a variety of sources including weathering of catchment soils and bedrock and the atmospheric deposition of terrestrial dust and sea salts (Aherne et al. 2002). Calcium $\left(\mathrm{Ca}^{2+}\right)$ was the dominant base cation in the study lakes with a mean concentration of $57.9 \mu \mathrm{eq} \mathrm{L} \mathrm{L}^{-1}$ (Tab. 1). Eightyfive percent of the lakes had concentrations less than $100 \mu$ eq $\mathrm{L}^{-1}$. Sodium $\left(\mathrm{Na}^{+}\right)$was the next dominant base cation with a mean concentration of $16.8 \mu \mathrm{eq} \mathrm{L} \mathrm{L}^{-1}$, followed by magnesium $\left(\mathrm{Mg}^{2+}\right.$ : mean $\left.=9.21 \mu \mathrm{eq} \mathrm{L} \mathrm{L}^{-1}\right)$ and potassium $\left(\mathrm{K}^{+}\right.$: mean $=3.87 \mu \mathrm{eq} \mathrm{L} \mathrm{L}^{-1}$; see Tab. 1$)$. Sixtysix of the 72 study lakes had total base cation concentrations less than $200 \mu \mathrm{eq} \mathrm{L} \mathrm{L}^{-1}$ (Fig. 3b), thereby classifying them as low base cation lakes (Sullivan et al. 1988).

Sulphate and $\mathrm{NO}_{3}{ }^{-}$are the most common acid anions affecting surface waters, with $\mathrm{SO}_{4}{ }^{2-}$ generally considered the most influential in acidification (Aherne et al. 2002). Sulphate concentrations in the study lakes range from 2.08 to $169 \mu \mathrm{eq} \mathrm{L}^{-1}$, with a mean concentration of $17.5 \mu \mathrm{eq} \mathrm{L} \mathrm{L}^{-1}$ (Tab. 1). Of the 72 study lakes, $18 \%$ had $\mathrm{SO}_{4}{ }^{2-}$ concentrations greater than $20 \mu \mathrm{eq} \mathrm{L}{ }^{-1}$ (Fig. 2a). Typically, dilute lakes with concentrations greater than $20 \mu \mathrm{eq} \mathrm{L} \mathrm{L}^{-1}$ are considered to be impacted by $\mathrm{S}$ deposition (Aherne et al. 2002).

The role of $\mathrm{N}$ in the acidification of surface waters has gained increased interest (Williams \& Tonnessen 2000). Nitrogen emissions resulting from the combustion of fossil fuels and agriculture have altered the global cycling of $\mathrm{N}$ (Vitousek et al. 1997). In particular, $\mathrm{NO}_{3}^{-}$has been shown to influence the acidity of alpine lakes during spring, when strong acid pulses result from rapid snow melt (Schindler 1988; Williams et al. 1993). Nitrate levels within the study lakes were generally much lower than $\mathrm{SO}_{4}{ }^{2-}$ ranging between $0.18 \mu \mathrm{eq} \mathrm{L}^{-1}$ and $9.71 \mu$ eq $\mathrm{L}^{-1}$ (mean $=1.73 \mu$ eq L $\mathrm{L}^{-1}$ : Tab. 1 \& Fig. 2 b).

Base cation concentrations showed significant increases with increased $\mathrm{SO}_{4}{ }^{2-}$ concentrations. This may indicate that the leaching of soil base cations is occurring within these catchments as a result of acid deposition. Sodium increased with increased sulphur deposition, however not significantly $\left(r_{\mathrm{s}}=0.209, p=0.078\right)$. With the exception of $\mathrm{K}^{+}$, all base cations decreased with increasing proportion of barren surfaces (areas al- most completely devoid of vegetation) in the catchment, however the relationship was only statistically significant for $\mathrm{Na}^{+}$and $\mathrm{Mg}^{2+}\left(r_{\mathrm{s}}=-0.652, p<0.001\right.$ and $r_{\mathrm{s}}=$ $-0.337, p=0.004$, respectively). Potassium concentrations increased in response to increased barren surfaces within the catchments $\left(r_{\mathrm{s}}=0.103, p=0.391\right)$. Barren landscapes were characterized by greater proportions of granodiorite and alkali feldspar lithologies, both of which contain significant amounts of $\mathrm{K}^{+}$. Further, barren surfaces do not support internal cycle of $\mathrm{K}^{+}$, typically associated with forested catchments. Sodium concentrations show a clear maritime influence, with levels decreasing significantly with increasing distance from the coastal areas of the Georgia Basin, $\left(r_{\mathrm{s}}=-0.403, p\right.$ $<0.001)$. Concentrations of $\mathrm{NO}_{3}{ }^{-}$and $\mathrm{SO}_{4}{ }^{2-}$ decreased significantly with increased distance from the major cities of Vancouver and Victoria $\left(r_{\mathrm{s}}=-0.401, p<0.001\right.$ and $r_{\mathrm{s}}=-0.339, p=0.004$, respectively). As would be expected, this indicates that greater amounts of deposition occurred in closer proximity to the major urban emission sources. The decrease in $\mathrm{SO}_{4}{ }^{2-}$ concentrations from the coastal regions may also indicate that $\mathrm{SO}_{4}{ }^{2-}$ derived naturally from the ocean is a significant source of $\mathrm{SO}_{4}{ }^{2-}$ in high-elevation surface waters close to the coastal regions of the Georgia Basin. Geological sources of $\mathrm{SO}_{4}{ }^{2-}$, such as the oxidation and weathering of sulphide and pyrites, may also contribute to surface water concentrations.

\subsection{Trace metals}

Metals in lake waters are derived from regional geological sources and from atmospheric deposition (Lydersen et al. 2002). In areas affected by acidic deposition, the mobility of metals from terrestrial sources increases, resulting in elevated concentrations in surface waters (Lydersen et al. 2002). At $\mathrm{pH}$ greater than 7 , trace metals are typically insoluble in water and complex with other particles (such as DOC: Schindler 1988). In the study lakes, trace metal concentrations were extremely low, with many lakes containing concentrations below detection limits.

With increasing acidification, aluminium (Al) concentrations commonly increase in surface waters (Lydersen et al. 2002). The toxicity of Al to aquatic biota is well-known (Baker \& Schofield 1982; Hutchinson et al. 1989) and typically occurs at $\mathrm{pH}$ levels $<5.0$ (Baker \& Schofield 1982). Mean total Al concentration in the study lakes was $113 \mu \mathrm{g} \mathrm{L}^{-1}$; however, none of the lakes had $\mathrm{pH}<5.0$, suggesting that toxic effects to aquatic organisms are not occurring. The positive correlation between $\mathrm{Al}$ and organic anions $\left(r_{\mathrm{s}}=0.591, p\right.$ $<0.001$ ) further supports this inference as Al commonly becomes complexed with organic materials resulting in minor effects on aquatic biota (Lydersen et al. 2002). A significant negative correlation, however, was observed between $\mathrm{Al}$ and $\mathrm{pH}\left(r_{\mathrm{s}}=-0.325, p=0.005\right)$. This may indicate that if the $\mathrm{pH}$ of lakes decrease further, $\mathrm{Al}$ may become increasingly mobile in surface waters. 
The deposition of lead has been attributed to emissions from transportation and mining industries (Bashkin 2002). Lead concentrations correlate with long range atmospheric deposition (Steinnes \& Henricksen 1993). Concentrations were very low in all the study lakes; ranging from below detection limits to $0.66 \mu \mathrm{g} \mathrm{L}^{-1}$ and concentrations decreased significantly with distance from major cities $\left(r_{\mathrm{s}}=-0.435, p<0.001\right)$.

Manganese $\left(\mathrm{Mn}^{2+}\right)$ concentrations in surface waters are typically not attributed to the direct influence of atmospheric deposition (Eisenreich 1980); however, $\mathrm{Mn}^{2+}$ concentrations have been found to increase in lakes experiencing low pH levels (Borg 1983). In the Georgia Basin, $\mathrm{Mn}^{2+}$ concentrations ranged from 0.43 to $68.1 \mu \mathrm{g}$ $\mathrm{L}^{-1}$ (mean $=3.24 \mu \mathrm{g} \mathrm{L}^{-1}$ ). Manganese was positively correlated with $\mathrm{SO}_{4}{ }^{2-}$ concentrations $\left(r_{\mathrm{s}}=0.419, p\right.$ $<0.001$ ), a trend also observed in Norwegian lakes by Steinnes \& Henriksen (1993). They attributed this increase in $\mathrm{Mn}^{2+}$ with $\mathrm{SO}_{4}{ }^{2-}$ to the leaching of $\mathrm{Mn}^{2+}$ from soils as a result of acidic precipitation. While the positive correlation between $\mathrm{Mn}^{2+}$ and $\mathrm{S}$ and $\mathrm{N}$ deposition supports this possibility, the relationships were not statistically significant.

\subsection{Factors influencing acidity and acid neutralising capacity}

Multiple linear regression was utilized to explore the relationship between catchment characteristics and the $\mathrm{pH}$ and ANC of the study lakes. Several studies have found relationships between lake ANC, $\mathrm{pH}$ and catchment land cover, geology, elevation and atmospheric deposition (Drever \& Zobrist 1992; Nanus et al. 2009; Marchetto et al. 1995). Accordingly, the current study included elevation, latitude and longitude, modelled S and $\mathrm{N}$ deposition, precipitation, land cover and geology.

Lake $\mathrm{pH}$ was primarily attributed to longitude, $\mathrm{S}$ deposition, precipitation and the amount of ice and glacier influencing the catchment. Similarly ANC was also related to longitude, precipitation and the proportion of ice and glacier within the catchment; however, bedrock type also significantly influenced lake ANC.

$$
\begin{gathered}
\mathrm{pH}=186-36.8 \times \text { longitude }-0.23 \times \mathrm{S} \text { deposition }- \\
-0.34 \times \text { precipitation }+0.10 \times \text { ice/glacier } \\
r^{2}=0.585 \\
\mathrm{ANC}=2656-20.6 \times \text { longitude }-0.02 \times \\
\times \text { precipitation }+10.7 \times \text { ice/glacier }+34.4 \times \text { rock } \\
r^{2}=0.582
\end{gathered}
$$

In the regressions, longitude represents distance from emission sources; lakes closer to the primary emission sources (Victoria and Vancouver) had lower $\mathrm{pH}$ and ANC values. Acid neutralising capacity and $\mathrm{pH}$ were also explained by precipitation. As precipitation increased, both ANC and $\mathrm{pH}$ decreased; increased precipitation is associated with higher loading of atmospheric pollutants in mountainous regions (Williams et al. 1996b). Acid neutralising capacity increased as the proportion of the catchment containing unknown buffering rocks (rocks that were unable to be classified into weathering and acid-buffering categories) increased ( $r_{\mathrm{s}}$ $=0.333, p=0.004)$ indicating that these are rock types with substantial acid buffering capabilities. Several studies (Berg et al. 2005; Nanus et al. 2009) have shown that the buffering capacity of rocks are significantly related to the ANC of surface waters, and that catchments containing rock types such as quartzite and granite are associated with ANC levels $<50 \mu \mathrm{eq} \mathrm{L}^{-1}$ (Nanus et al. 2009).

The $\mathrm{pH}$ and the ANC of the study lakes was influenced by the proportion of ice and glacier cover in the catchment. Although not significant, $\mathrm{pH}$ increased with increased glacier and ice cover $\left(r_{\mathrm{s}}=0.115, p=0.333\right)$. This could be the result of the composition of glacial melt waters. Lakes fed by glacial melt waters receive greater loads of suspended sediments as a result of the production of glacial flour (Sommaruga et al. 1999). Moreover, depending on the nature of the bedrock, glacial melt waters have been shown to be high in base cation concentrations, especially $\mathrm{Ca}^{2+}$ and $\mathrm{K}^{+}$(Anderson et al. 1997). Glacial melt waters are also typically low in DOC (Sammaruga et al. 1999); therefore the influence of acidic organic anions is negligible.

The multiple regression analysis indicated that $\mathrm{S}$ deposition was a primary factor influencing the $\mathrm{pH}$ of high-elevation lakes in the Georgia Basin. Acidic deposition occurs when sulphur dioxide $\left(\mathrm{SO}_{2}\right)$ is oxidised in the atmosphere forming sulphuric acid (Ahrens 2003). The major source of $\mathrm{SO}_{2}$ emissions within the Georgia Basin is the burning of fossil fuels, especially from the marine sector (Environment Canada 2004). The lakes receiving the highest $\mathrm{S}$ deposition were characterized by low $\mathrm{pH}$ and ANC levels.

\subsection{Critical loads of acidity and nutrient nitrogen}

The mean $\operatorname{CL}(A)$ for the study lakes was $90.1 \mathrm{meq}$ $\mathrm{m}^{-2} \mathrm{y}^{-1}$ (median: 68.5. meq $\mathrm{m}^{-2} \mathrm{y}^{-1}$, Fig. 4), which is similar to lakes in acid sensitive regions in eastern Canada (Henriksen et al. 2002). In contrast, mean S deposition was approximately half $\left(23.2 \mathrm{meq} \mathrm{m}^{-2} \mathrm{y}^{-1}\right)$. Approximately $18 \%(\mathrm{n}=13)$ of the study lakes received $\mathrm{S}$ deposition above their $\mathrm{CL}(A)$ (Fig. 4). All lakes are protected if acid deposition is below the minimum $\mathrm{CL}(A)$. However, to discard outliers, account for uncertainties, and ensure that a sufficient percentage of lakes are protected, a $95 \%$ protection limit for the $\operatorname{CL}(A)$ is commonly used. The pentile $\mathrm{CL}(A)$ for the study region was approximately 10 meq $\mathrm{m}^{-2} \mathrm{y}^{-1}$.

Modelled $\mathrm{S}$ and $\mathrm{N}$ deposition to the study sites were highly correlated $\left(\mathrm{r}_{\mathrm{s}}=0.855, p=<0.001\right)$; however, $\mathrm{N}$ deposition was more than twice that of S (mean: $8.65 \mathrm{~kg}$ $\mathrm{ha}^{-1} \mathrm{y}^{-1}$, Tab. 1). Along with surface water acidification, increases in the $\mathrm{N}$ deposition has been linked to terrestrial ecological changes, including soil biogeochemistry and plant community diversity. In contrast, 


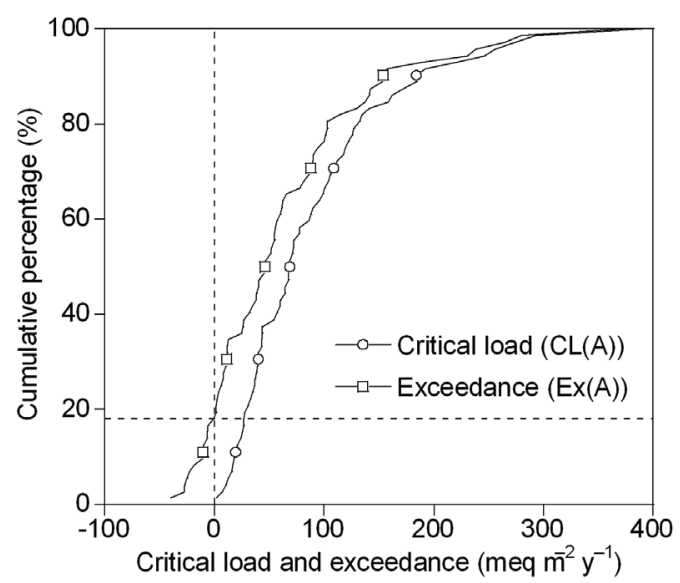

Fig. 4. Cumulative distribution functions (\% of lakes) for critical load of acidity $[\mathrm{CL}(A)]$ and exceedance $[\operatorname{Ex}(\mathrm{A})]$ for study lakes $(\mathrm{n}=$ 72). Note: for presentational purposes the sign on exceedance has been reversed, i.e., negative values indicate exceedance of critical load. Approximately $18 \%$ of the lakes received sulphate deposition in excess of the CL $(A)$.
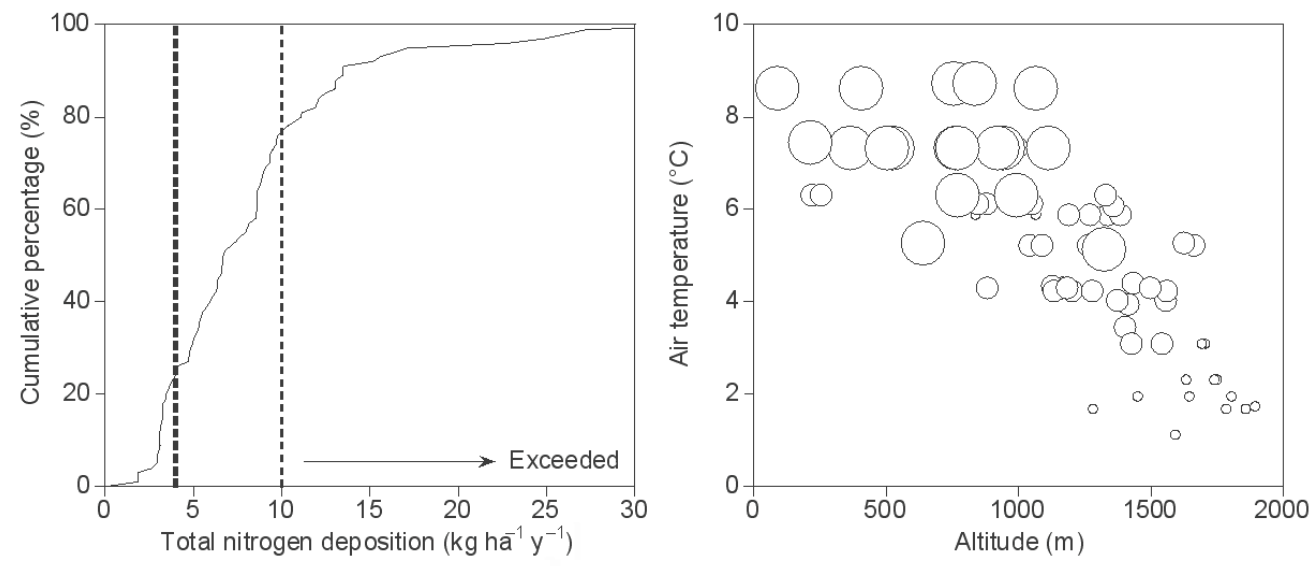

Fig. 5. Left panel: cumulative distribution of total nitrogen deposition to the study lakes for the period 2005-2006. Dashed vertical lines indicate the empirical critical loads for nutrient nitrogen of 4.0 (heavy dashed) and 10.0 (lighted dashed) $\mathrm{kg} \mathrm{ha}^{-1} \mathrm{y}^{-1}$. Right panel: relationship between air temperature, altitude and nitrogen deposition. Small open circles denote lakes receiving $<4 \mathrm{~kg}^{-1}$ $\mathrm{y}^{-1}$, medium circles denote lakes receiving between 4 and $10 \mathrm{~kg} \mathrm{ha}^{-1} \mathrm{y}^{-1}$ and large circles denote lakes receiving $>10 \mathrm{~kg} \mathrm{ha}{ }^{-1} \mathrm{y}^{-1}\left(1 \mathrm{~kg}^{-1}\right.$ $\mathrm{N} \mathrm{ha}^{-1}=7.14 \mathrm{meq} \mathrm{m}^{-2}$ ).

primary production in almost all surface waters is phosphorus-limited however, increased $\mathrm{N}$ loading to $\mathrm{N}$ limited surface waters can result in changes in phytoplankton communities, increased biomass and eutrophication (Bergstrom \& Jansson 2006). Approximately $27 \%$ of the study catchments receive $\mathrm{N}$ deposition above the empirical critical load of $10 \mathrm{~kg} \mathrm{~N} \mathrm{ha}^{-1} \mathrm{y}^{-1}$ (range of 5-15 $\mathrm{kg} \mathrm{N} \mathrm{ha}^{-1} \mathrm{y}^{-1}$ ) for alpine terrestrial ecosystems. Bowman et al. (2006) similarly found an empirical $\mathrm{N}$ critical load of $10 \mathrm{~kg} \mathrm{~N} \mathrm{ha}^{-1} \mathrm{y}^{-1}$ for changes in alpine plant community composition, but recommend a lower critical load of $4 \mathrm{~kg} \mathrm{~N} \mathrm{ha}^{-1} \mathrm{y}^{-1}$ to protect against changes in individual alpine species. Although $77 \%$ of the study lakes exceeded this critical load (Fig. 5), the highest elevation sites with shorter growing seasons received the lowest deposition loads (Fig. 5). Furthermore, all study lakes received N-deposition in excess of the critical load of $1.5 \mathrm{~kg} \mathrm{ha}^{-1} \mathrm{y}^{-1}$ for the eutrophication of aquatic ecosystems outlined by Baron (2006).

\subsection{Overall acid sensitivity}

High-elevation lakes in the Georgia Basin are sensitive to atmospheric acid deposition. Approximately 47\% of the study lakes had ANC concentrations less than 50 $\mu$ eq $\mathrm{L}^{-1}$, suggesting that almost half are unable to counteract the effects of current or increased deposition loads (Sullivan et al. 2004). The low base cation concentrations observed in the study lakes are indicative of low weathering rates. Typically, weathering rates in alpine regions are low and decrease with increasing elevation (Drever \& Zobrist 1992). Mongeon et al. (2010, this issue) estimated weathering rates at 19 sites in the Georgia Basin using the PROFILE model (Warvinge \& Sverdrup 1992); the lowest rates were found at highelevation alpine sites.

Land cover and geology undoubtedly influence the acid sensitivity of high-elevation catchments. In the 
southern Appalachian mountains, acid-sensitive lakes were predicted to occur in regions underlain by basepoor bedrock (Sullivan et al. 2007). Similarly, in the US Rocky Mountains, acid-sensitivity was related to bedrock geology (Nanus et al. 2009). The dominant geology of the Georgia Basin primarily consists of bedrock with low buffering capacities. Moreover, the primary land cover in the study catchments consisted of barren, exposed bedrock. In general, high-elevation catchments within the Georgia Basin are unable to efficiently buffer incoming acidic deposition.

Sulphur deposition is the primary anthropogenic pollutant affecting the high-elevation lakes in the Georgia Basin; $18 \%$ of the study lakes received $\mathrm{S}$ deposition in excess of their $\mathrm{CL}(A)$. Emissions of $\mathrm{SO}_{2}$ are expected to increase owing to the anticipated growth of Vancouver and Victoria. The Greater Vancouver Regional District (GVRD 2003) has forecasted that the emissions of $\mathrm{SO}_{2}$ will increase by $23 \%$ by the year 2020 . The role of $\mathrm{N}$ deposition in the acidification of surface waters has gained increased interest (Vitousek 1997). Nitrogen deposition leading to episodic acidification of surface waters during snow melt has been reported in the catchments of the Colorado Front Range (Baron 1992; Williams et al. 1996a), the Adirondack Mountains (Sullivan et al. 1996) and in high-elevation basins in the Sierra Nevada Mountains in California (Williams et al. 1993). These symptoms have been observed in alpine catchments with deposition rates as low as $3 \mathrm{~kg} \mathrm{ha}^{-1} \mathrm{y}^{-1}$ (Campbell et al. 2000). Emissions of $\mathrm{N}$ oxides $\left(\mathrm{NO}_{\mathrm{x}}\right)$ within the Georgia Basin are also expected to increase in the coming years.

\section{CONCLUSIONS}

This study suggests that high-elevation regions within the Georgia Basin are sensitive to acidification from long-range atmospheric deposition from both local and distant sources. Moreover, surface water chemistry suggests that acidification has occurred under current emission levels and a significant number of catchments currently receive $\mathrm{S}$ deposition in excess of their $\mathrm{CL}(A)$. These regions are unable to efficiently buffer acidic inputs owing to the dominance of low buffering bedrock in their catchments and lack of vegetative land cover. In contrast, lakes at higher elevations show the unusual trend of having increased $\mathrm{pH}$ levels. This is most likely attributed to the decreased influence of organic anions and the abundance of glacial land cover contributing sediment rich melt waters to the catchments.

Increased monitoring of surface water chemistry and atmospheric deposition is imperative in further assessing the impacts on these catchments. Although S deposition has been considered the primary pollutant in acidification of surface waters, the role of $\mathrm{N}$ should not be ignored and research should be conducted to further understand the complex biogeochemical processes that lead to the acidification and eutrophication of high-ele- vation catchments and surface waters as a result of $\mathrm{N}$ deposition.

\section{ACKNOWLEDGEMENTS}

Research was funded by both the Environment Canada Georgia Basin Action Plan and by the Environment Canada Acid Rain program. This research was undertaken, in part, thanks to funding from the Canada Research Chairs Program and an NSERC Discovery grant. Chemical analyses were conducted by ALS Analytical Laboratories, Environment Canada Pacific Environmental Science Centre and the University of Waterloo Isotope Laboratory. The multi-year CMAQ model runs were conducted at the University of British Columbia, and made available by Colin di Cenzo of Environment Canada. Thanks goes to all field assistants and laboratory technicians involved in the collection and analysis of water samples and to Dr. John Gibson of the Alberta Research Council for delineating catchment and lake boundaries. Access was granted by BC Parks to sample lakes within the boundaries of provincial parks. A special thanks goes to the late Beverley A. Raymond who initiated the project and contributed greatly to the site selection.

\section{REFERENCES}

Achermann, B. \& R. Bobbink (Eds). 2003. Empirical Critical Loads for Nitrogen. Environmental Documentation No. 164, Swiss Agency for the Environment, Forests and Landscape, Berne, Switzerland: 327 pp.

Aherne, J., M. Kelly-Quinn \& E.P. Farrell. 2002. A survey of lakes in the Republic of Ireland: hydrochemical characteristics and acid sensitivity. Ambio, 31: 452-459.

Ahrens, C. D. 2003. Meteorology Today; An Introduction to Weather, Climate and the Environment. Thomson Learning Inc., USA: 624 pp.

Anderson, S.P., J.I. Drever \& N.F. Humphrey. 1997. Chemical weathering in glacial environments. Geology, 25: 399-402.

Baker, J.P. \& C.L. Schofield. 1982. Aluminium toxicity to fish in acidic waters. Water Air Soil Pollut., 18: 289-309.

Baron, J. (Ed.). 1992. Biogeochemistry of a subalpine ecosystem: Loch Vale Watershed. Ecological Studies Series 90. Springer Verlag, New York: 236 pp.

Baron, J. 2006. Hindcasting nitrogen deposition to determine an ecological critical load. Ecol. Appl., 16: 433-439.

Bashkin, V.N. 2002. Modern Biogeochemistry. Kluwer Academic Publishers, New York: 561 pp.

Berg, N.H., A. Gallegos, T. Dell, J. Frazier, T. Procter, J. Sickman, S. Grant, T. Blett \& M. Arbaugh. 2005. A screening procedure for identifying acid-sensitive lakes from catchment characteristics. Environ. Model. Assess., 105: 285-307.

Bergstrom, A.K. \& M. Jansson. 2006. Atmospheric nitrogen deposition has caused nitrogen enrichment and eutrophication of lakes in the northern hemisphere. Glob. Change. Biol., 12: 635-643.

Borg, H. 1983. Trace metals in Swedish natural fresh waters. Hydrobiologia, 101: 27-34.

Bowman, W.D., J.R. Gartner, K. Holland \& M. Wiedermann. 2006. Nitrogen critical loads for alpine vegetation and terrestrial ecosystem response: are we there yet? Ecol. Appl., 16: 1183-1193.

Campbell, D.H., J.S. Baron, K.A. Tonnessen, P.D. Brooks \& P.F. Schuster. 2000. Controls on the nitrogen flux in al- 
pine/subalpine watersheds in Colorado. Water Resour. Res., 36: 37-47.

Clow, D.W., R.G. Striegl, L. Nanus, M.A. Mast, D.H. Campbell \& D.P. Krabbenhoft. 2002. Chemistry of high-elevation lakes in seven national parks in the western United States. Water Air Soil Pollut. Focus, 2: 139-164.

Daly, C., R.P. Neilson \& D.L. Philips. 1994. A statistical-topographic model for mapping climatological precipitation over mountainous terrain. J. Appl. Meteorol., 33: 140-158.

Di Cenzo, C. \& M. Lepage. 2003. Application of CMAQ over the Pacific Northwest to determine the significance of the international trans-boundary flows of air contaminants. Second Annual CMAS Models-3 User's Conference - One Atmosphere, One Community, One Modelling System: Models-3, October 27-29, Research Triangle Park, Raleigh, North Carolina: 5 pp.

Drever, J.I. \& J. Zobrist. 1992. Chemical weathering of silicate rocks as a function of elevation in the southern Swiss Alps. Geochim. Cosmochim. Acta, 56: 3209-3216.

Eder, B.K. \& S. Yu. 2006. A Performance Evaluation of the 2004 Release of Models-3 CMAQ. Atmos. Environ., 40: 48114824.

Eisenreich, S.J. 1980. Atmospheric input of trace metals to Lake Michigan. Water Air Soil Pollut., 13: 287-301.

Environment Canada. 2004. Characterization of the Georgia Basin/Puget Sound Airshed. Environment Canada, Georgia Basin Action Plan: 140 pp.

Goldich, S.S. 1938. A study in rock weathering. J. Geol., 46: $17-58$.

GVRD. 2003. Forecast and Backcast of the 2000 Emission Inventory for the Lower Fraser Valley Airshed 1985-2025. Greater Vancouver Regional District, Policy \& Planning Department: $38 \mathrm{pp}$.

Henriksen, A., P.J. Dillon \& J. Aherne. 2002. Critical loads of acidity for surface waters in south-central Ontario, Canada: regional application of the steady-state water chemistry (SSWC) model. Can. J. Fish. Aquat. Sci., 59: 1287-1295.

Herlihy, A.T., P.R. Kaufmann, M.R. Church, P.J. Wigington Jr., J.R. Webb \& M.J. Sale. 1993. The effects of acidic deposition on streams in the Appalachian Mountain and Piedmont region of the Mid-Atlantic United States. Water Resour. Res., 29: 2687-2703.

Hutchinson, N.J., K.E. Holtze, J.R. Munro \& T.W. Pawson. 1989. Modifying effects of life stage, ionic strength and post-exposure mortality on lethality of $\mathrm{H}^{+}$and $\mathrm{Al}$ to lake trout and brook trout. Aquat. Toxicol., 15: 1-26.

Jeffries, D.S. 1997. 1997 Canadian Acid Rain Assessment Volume 3. The effects on Canada's lakes, river and wetlands. Environment Canada: 178 pp.

Jeffries, D.S., R.G. Semkin, J.J. Gibson \& I. Wong. 2010. Recently surveyed lakes in northern Manitoba and Saskatchewan, Canada: characteristics and critical loads of acidity. J. Limnol., 69(Suppl. 1): 45-55. DOI: 10.3274/ JL10-69-S1-06.

Kahl, J.S., S.A. Norton, R.K. MacRae, T.A. Haines \& R.B. Davis. 1989. The influence of organic acidity on the acidbase chemistry of surface waters in Maine, USA. Water Air Soil Pollut., 46: 221-233.

Lien, L., G.G. Raddum, A. Fjellheim \& A. Henriksen. 1996. A critical limit for acid neutralizing capacity in Norwegian surface waters, based on new analyses of fish and invertebrates responses. Sci. Tot. Environ., 177: 173-193.

Lydersen, E., S. Lofgren \& R.T. Arnesen. 2002. Metals in Scandanavian surface waters: effects of acidification, liming and potential reacidification. Crit. Rev. Environ. Sci. Technol., 32: 73-295.

Lydersen, E., T. Larssen \& E. Fjeld. 2004. The influence of total organic carbon (TOC) on the relationship between acid neutralizing capacity (ANC) and fish status in Norwegian lakes. Sci. Tot. Environ., 326: 63-69.
Marchetto, A., R. Mosello, R. Psenner, A. Barbieri, G. Bendetta, D. Tait \& G.A. Tartari. 1994. Evaluation of the level of acidification and the critical loads for alpine lakes. Ambio, 23: 150-154.

Marchetto, A., R. Mosello, R. Psenner, G. Bendetta, A. Boggero, D. Tait \& G.A. Tartari. 1995. Factors affecting water chemistry of alpine lakes. Aquatic Sciences: Research Across Boundaries, 57: 81-89.

Meidinger, D. \& J. Pojar. 1991. Ecosystems of British Columbia. Research Branch BC Ministry of Forests, No. 6: 342 pp.

Mongeon, A, J. Aherne \& S.A. Watmough. 2010. Steady-state critical loads of acidity for forest soils in the Georgia Basin, British Columbia. J. Limnol., 69(Suppl. 1): 193-200. DOI: 10.3274/JL10-69-S1-19.

Moran, M.D., Q. Zheng, R. Pavlovic, S. Cousineau, V.S. Bouchet, M. Sassi, P.A. Makar, W. Gong \& C. Stroud. 2008. Predicted acid deposition critical-load exceedances across Canada from a one-year simulation with a regional particulate-matter model. Proceedings of the $15^{\text {th }}$ Joint AMS/A\&WMA Conference on Applications of Air Pollution Meteorology, January 21-24, New Orleans, American Meteorological Society, Boston: $20 \mathrm{pp}$.

Mosello, R., A. Marchetto, A. Boggero \& G.A. Tartari. 1990. Relationships between water chemistry, geographical and lithological features of the watershed of alpine lakes located in NW Italy. Int. Ver. Theoret. Ange. Limnol., 24: 155-157.

Mosello, R., B.M. Wathne, L. Lien \& H.J.B. Birks. 1995. AL:PE projects: Water chemistry and critical loads. Water Air Soil Pollut., 85: 493-498.

Nanus, L., M.W. Williams, D.H. Campbell, K.A. Tonnessen, T. Blett \& D.W. Clow. 2009. Assessment of lake sensitivity to acidic deposition in national parks of the Rocky Mountains. Ecol. Appl., 19: 961-973.

Nilsson, J. \& P. Grennfelt (Eds). 1988. Critical loads for sulphur and nitrogen. Miljørapport 1988:15, NORD 1998:097 Nordic Council of Ministers, Copenhagen, Denmark: $418 \mathrm{pp}$.

Oliver, B.G., E.M. Thurman \& R.L. Malcolm. 1983. The contribution of humic substances to the acidity of colored natural waters. Geochim. Cosmochim. Acta, 47: 2031-2035.

Psenner, R. 1989. Chemistry of high mountain lakes in siliceous catchments of the Central Eastern Alps. Aquat. Sci., 51: 108-128.

Rogora, M., J. Massaferro, A. Marchetto, G. Tartari \& R. Mosello. 2008. The water chemistry of some shallow lakes in Northern Patagonia and their nitrogen status in comparison with remote lakes in different regions of the globe. $J$. Limnol., 67(2): 75-86.

Schindler, D.W. 1988. Effects of acid rain on freshwater ecosystems. Science, 239: 149-157.

Scott, K.A., B. Wissel, J.J. Gibson \& S.J. Birks. 2010. Chemical characteristics and acid sensitivity of boreal headwater lakes in northwest Saskatchewan. J. Limnol., 69(Suppl. 1): 33-44. DOI: 10.3274/JL10-69-S1-05.

Sommaruga, R., R. Psenner, E. Schafferer, K.A. Koinig \& S. Sommaruga-Wograth. 1999. Dissolved organic carbon concentration and phytoplankton biomass in high-mountain lakes of the Austrian Alps: potential effect of climatic warming on UV underwater attenuation. Arct. Antarct. Alp. Res., 31: 247-253.

Steinnes, E. \& A. Henriksen. 1993. Metals in small Norwegian lakes: relation to atmospheric deposition of pollutants. Water Air Soil Pollut., 71: 167-174.

Stuchlik, E., J. Kopacek, J. Fott \& Z. Horicka. 2006. Chemical composition of the Tatra Mountain lakes: response to acidification. Biologia Bratislava, 61: S11-S20.

Sullivan, M.A. \& S.C. Samis. 1988. Assessment of acidification potential of selected Lower Mainland and Vancouver Island, British Columbia streams. Canadian Technical Re- 
port of Fisheries and Aquatic Sciences. Ottawa: Canada. Dept of Fisheries and Oceans: $106 \mathrm{pp}$.

Sullivan, T.J., J.M. Eilers, M.R. Church, D.J. Blick, K.N. Eshleman, D.H. Landers \& M.S. DeHann. 1988. Atmospheric wet sulphate deposition and lake water chemistry. Nature, 331: 607-609.

Sullivan, T.J., B.J. Cosby, A.T. Herlihy, J.R. Webb, A.J. Bulger, K.U. Snyder, P.F. Brewer, E.H. Gilbert \& D.L. Moore. 2004. Regional model projections of future effects on sulphur and nitrogen deposition on streams in the southern Appalachian Mountains. Water Resour. Res., 40: W02101.

Sullivan, T.J., J.R. Webb, K.U. Snyder, A.T. Herlihy \& B.J. Cosby. 2007. Spatial distribution of acid-sensitive and acid-impacted streams in relation to watershed features in the southern Appalachian mountains. Water Air Soil Pollut., 182: 57-71.

Swain, L.G. 1985. Chemical sensitivity of lakes in British Columbia to acidic inputs. British Columbia Ministry of Environment, Victoria, B.C.: 28 pp.

UBA 2004. Manual on Methodologies and Criteria for Modelling and Mapping Critical Loads \& Levels and Air Pollution Effects, Risks and Trends. UNECE Convention on Long-range Transboundary Air Pollution, Federal Environmental Agency (Umweltbundesamt), Berlin: $254 \mathrm{pp}$.

Vitousek, P.M., J.P. Aber, R.W. Howarth, G.E. Likens, P.A. Matson, D.W. Schindler, W.H. Schlesinger \& D.G. Til- man. 1997. Human alterations on the global nitrogen cycle: sources and consequences. Ecol. Appl., 7: 737-750.

Warfvinge, P. \& H. Sverdrup. 1992. Calculating critical loads of acid deposition with PROFILE - A steady-state soil chemistry model. Water Air Soil Pollut., 63: 119-143.

Wiens, J.H. 1987. Sensitivity of Western and Northern Canada soils and Geology to Acidic Input. Technical Committee for the Long-Range Transport of Atmospheric Pollutants in Western and Northern Canada, Coordinating Committee on Soil and Geology Sensitivity Mapping (Canada), Victoria, British Columbia.

Williams, M.W., A.D. Brown \& J.M. Melack. 1993. Geochemical and hydrological controls on the composition of surface water in a high-elevation basin, Sierra Nevada, California. Limnol. Oceanogr., 38: 775-797.

Williams, M.W., J.S. Baron, N. Caine, R. Sommerfeld \& R. Sanford Jr. 1996a. Nitrogen saturation in the Rocky Mountains. Environ. Sci. Technol., 30: 640-646.

Williams, M.W., M. Losleben, N. Caine \& D. Greenland. 1996b. Changes in climate and hydrochemical responses in a high-elevation catchment in the Rocky Mountains, USA. Limnol. Oceanogr., 41: 939-946.

Williams, M.W. \& K. Tonnessen. 2000. Critical loads for inorganic nitrogen deposition in the Colorado Front Range, USA. Ecol. Appl., 10: 1648-1665. 